\title{
IDENTITY Verification AND SOCIETAL Challenges: EXPLAINING THE GAP BETWEEN SERVICE PROVISION AND DEVELOPMENT OUTCOMES ${ }^{1}$
}

\author{
Kathy McGrath \\ Department of Computer Science, Brunel University, \\ Uxbridge, Middlesex, UNITED KINGDOM \{Kathy.McGrath@brunel.ac.uk\}
}

\begin{abstract}
The capability to produce a secure, reliable form of identification on request is taken for granted by many citizens, especially those living in countries with advanced economies. This capability provides numerous development benefits for individuals, from accessing government and business services to establishing their right of residence and employment in a region. Furthermore, nationwide use of reliable means of identification can help to combat crime and illegal immigration. Efforts to introduce identity verification services in Nigeria have been presented by policymakers as an intervention that would lead to a wide range of such development outcomes. However, these benefits are proving difficult to realize. The use of identity smart cards aims to improve the current situation in which most Nigerian citizens do not possess reliable means of identifying themselves by, say, an international passport or driving license. Although IS research is well aware that the provision of a service does not of itself deliver development outcomes, the nature and role of ICT-based services in development is not well understood. Therefore, this research contributes in two ways. First, it directly addresses the relationship between ICTs and development policies and outcomes, with which much IS research engages minimally or not at all. Second, it explains citizens' suspicion of the intervention in Nigeria and then uses secondary data from more successful cases to address the question of why some countries achieve desired development outcomes from the provision of identity verification services while others do not.
\end{abstract}

Keywords: Social mechanism, trust, distrust, suspicion, ambivalence, national identity cards, comparative study, socioeconomic development, financial reform, generative mechanism

\section{Introduction}

Identity verification is a necessary and legitimate requirement to enable individuals to claim their right to live and work in a region, and gain access to important services such as banking and loans. Within the more affluent societies, this requirement is often met by an international passport or driving license (Whitley et al. 2014). However, in countries

\footnotetext{
${ }^{1}$ Ann Majchrzak, M. Lynne Markus, and Jonathan Wareham were the accepting senior editors for this paper.

(C)2016. The Author. Published by the Management Information Systems Research Center at the University of Minnesota. This is an open access article under the terms of the Creative Commons Attribution CC BY License, which permits use, distribution, and reproduction in any medium, provided the original work is properly cited.
}

where the majority of citizens live on a couple of dollars a day, ownership of such documents is rare and hence secure, reliable means of identification may not be in widespread use. In these circumstances, crime and illegal immigration can flourish, and individuals may encounter obstacles when trying to access important and valued services (World Bank 2014).

In this context, the national identity card is an alternative form of identity verification favored by many governments. National identity cards are in use in more than 100 countries worldwide (Privacy International 2011). Such schemes operate in developed and developing countries (DCs), although some are voluntary in the sense that citizens do not need to carry or even possess the official identity card. In general, most DCs have identity cards and they are compulsory (ibid.). Often, policymakers directly link the use of 
ICT-based identity verification with socioeconomic development opportunities for their citizens. Such claims may state that the use of identity cards will widen access to consumer credit and job opportunities, and improve health and pension planning (for example, NIMC 2009).

However, the gap between production of the strategy document for the service and the realization of development outcomes is vast. National identity verification systems entail considerable technical and managerial challenges in their implementation and use. Crucially, though, there is significant global debate about both the potential of such systems to address the societal challenges outlined above and the implications for registrants' civil liberties as a result of their deployment (Allonby 2009; Ramakumar 2010; Whitley and Hosein 2010b). In practice, outcomes are mixed, socioeconomic development is uneven, and some countries have very poor records with implementing IS innovations (Avgerou 2008; Heeks 2002). Notable successes, such as the Estonian identity card system (Whitley and Hosein 2010a), contrast sharply with other countries' frustrated attempts to develop substantial ICT capabilities and infrastructures to support their public services and major industries. Furthermore, the relationship between ICT success and the development policies and achievements in the countries concerned is not well understood. Mechanism-based research, which seeks to explain such diverse outcomes when attempting similar interventions in different contexts (McGrath 2013; Pawson 2000), has significant potential for addressing these enduring concerns.

The focus of this paper is on three case studies of national identity verification systems and the development of a mechanism-based account to explain the outcomes achieved in each case. The remainder of this paper is organized as follows. The next section outlines the importance of trust and distrust in explaining the implementation outcomes from identity verification systems. A narrative description of three empirical case studies of such systems is then provided. In the analysis section, the issue of how trust and distrust were manifested in each case, as ambivalence or suspicion, and the mechanisms that account for such manifestations are addressed. Finally, a summary of the implications of the work and an outline for further research directions is presented.

\section{Accounting for the Outcomes of Implementing Identity Verification}

National identity verification systems are not uniform in nature. Aside from the consideration of whether possession and use of the identity card is compulsory or voluntary, such systems can be paper-based or adopt smart card technology; they may (or may not) incorporate biometrics, such as facial images, fingerprints, iris scans, or DNA information; they can be based on a single unique identifier for each individual or a range of such identifiers; and the data captured may be stored in a centralized database or held in several regional or departmental databases which are not harmonized ${ }^{2}$ (Whitley and Hosein 2010a). Implementation decisions such as these affect the extent to which the systems are perceived to erode civil liberties and present security challenges for governments.

For example, in 2010, India began the process of creating the world's largest biometric database, complete with fingerprints and iris scans of its 1.2 billion citizens and residents (Yadav 2013). Each person is being allocated a unique identifier (UID) which provides access to a wide range of benefits and services. Although advised that enrollment is voluntary, individuals have discovered that their UID is necessary to

get food in the public distribution system, to get work, to get cooking gas, to receive scholarships and pensions, to open and operate bank accounts, to register marriages, in rental agreements and sales deeds and wills (Ramanathan 2014).

Consequently, the poor especially have little option but to enroll. Identity verification systems such as this, which employ smart cards, biometrics, and data harmonization, and whose use is compulsory (in law or of necessity), are especially contentious because of both their surveillance potential and the security threat posed by using a single identifier to access huge volumes of data. While such systems are being introduced in parts of sub-Saharan Africa, the Middle East, South America, and Asia, including the Indian subcontinent, they have been opposed on the grounds of violating civil liberties, and ultimately rejected, in common law countries such as the United Kingdom, the United States, Canada, and Australia (Whitley and Hosein 2010a; World Bank 2014). The picture is mixed in continental Europe where the systems have support in Estonia and Moldova, but are curtailed by strong data protection laws in other countries, such as Germany, where biometric smart cards are compulsory but legislation prevents the creation of a central database (Whitley and Hosein 2010a).

Clearly, public perceptions are important to the success of such systems. Enrollment and verification are complex tasks

\footnotetext{
${ }^{2}$ Contrary to centralized or harmonized databases, accessing personal data held in nonharmonized databases requires knowledge of multiple identifiers and the relationships among them.
} 
in themselves, which will be threatened further if registrants' suspicion of government is such that they try to avoid enrolling or manipulate the verification processes. Indeed, their developmental potential notwithstanding, it is realistic to expect some distrust of such systems, given the surveillance opportunities and security issues they present. Hence, building trust has been identified as crucial by both academics and policymakers (Islam and Gronlund 2010; World Bank 2014). The argument adopted in this paper is that the relationship between a citizen and the state is complex and multifaceted; it involves simultaneous trust and distrust as separate dimensions, and such coexistence is not only commonplace but can be highly productive (Lewicki et al. 1998). In this view, trust and distrust are not alternatives, at opposite ends of a continuum; rather, they coexist as separate dimensions of the same relationship - frequently in tension, subject to change as the relationship matures and its scope expands, and irreducible to some average sentiment. These ideas have their foundations in Luhmann's (1979) work, which conceives of trust and distrust in terms of what they do. For Luhmann, they are functionally equivalent means to reduce uncertainty and complexity because they produce confident positive or confident negative expectations regarding another's conduct, although trust does so more cost efficiently than distrust in psychological terms.

For example, an individual may have high trust in her government's ability to manage fiscal policy and provide for her pension, but distrust it in other ways owing to, say, a poor experience with its error-prone administrative systems. This ambivalence, and the tension it produces, can be productive if it prompts the pension recipient to check her statements to guard against processing errors. Furthermore, the dimensions of the relationship may expand, for example, if she decides to invest in government bonds, and it will mature over time so that she has a better understanding of when she can trust the government and when she should exhibit caution and take precautions. On the other hand, if a new government comes to power, the individual may experience low trust in their fiscal management capabilities. Combined with a distrust of their administrative systems, which may even increase in these uncertain conditions, the individual becomes increasingly suspicious of the government's actions. This research is premised on the view that these two perspectives of ambivalence and suspicion are crucial in explaining why some governments are more successful than others with introducing identity verification. Based on this premise, the goal of this research is to derive the social (or generative) mechanisms that give rise to these different manifestations of trust and distrust, that is, to identify the structures, processes, and events that explain observed outcomes in each case (McGrath 2013; Pawson 2000).

\section{Research Methodology}

Given this research goal, a comparative case study analysis was undertaken. The focal case was the problematic introduction of identity verification services in Nigeria, which was compared with more successful implementations in Bangladesh and the United Arab Emirates (UAE). The research adopted a retroductive process (Sayer 2000) within an interpretivist epistemology, using both primary and secondary data. This involved hypothesizing the generative mechanisms that explained initial observed outcomes, and then treating the hypothesized mechanisms as candidate explanations that could be refined through further empirical study (ibid.). This work started in August 2009 and is ongoing. Throughout that time, the Nigerian government has been attempting to introduce identity cards with limited success. The initial analysis of the case revealed that low trust was significant in explaining the poor outcomes. Further, primary and secondary research suggested a link between trust and civil liberties related to the use of identity cards. Two further cases were then selected for analysis where the adoption of biometrics, data harmonization, and compulsory use suggested that civil liberties were again an issue, yet the cards had been successfully introduced.

Initial primary data were collected at the Nigerian Identity Management Commission (NIMC) in Abuja, and involved interviews with the directors and staff of the commission and their business and technical partners. Subsequently, 15 online and telephone interviews were conducted with Nigerian citizens, most of whom were located in large urban areas in different parts of the country, including Lagos, Port Harcourt, and Abuja. Convenience and snowball sampling (Bryman 2001) were used to identify citizen participants. Contact was facilitated by a member of the Nigerian cohort of international students studying at the author's workplace, five of whom also participated in this study. Further primary research involved four meetings with academics and practitioners experienced in the research area, including an interview with a member of the implementation team for the UAE case. These findings were complemented by secondary sources, including citizen survey data dealing with Nigeria's development priorities and challenges, in particular the development goals of the proposed identity verification service. Table 1 lists the different types of data collected and the purpose in doing so. All primary and secondary data were collected by the author, except item 1, which was undertaken by a research assistant working under the author's supervision in the early stages of this research. ${ }^{3}$

\footnotetext{
${ }^{3}$ The research assistant was a Nigerian national funded by a grant awarded to the author of this paper (as Principal Investigator) by the Engineering and Physical Sciences Research Council.
} 


\begin{tabular}{|c|c|c|c|}
\hline No. & Date & Purpose & Data Type \\
\hline 1 & $\begin{array}{l}\text { Summer } 2009 \\
\text { Autumn } 2010\end{array}$ & $\begin{array}{l}\text { To determine the proposed develop- } \\
\text { ment objectives of the Nigerian identity } \\
\text { verification service and monitor } \\
\text { progress of the implementation }\end{array}$ & $\begin{array}{l}\text { Interview records (35) and observation notes (7) } \\
\text { collected at the Nigerian Identity Management } \\
\text { Commission (NIMC). }\end{array}$ \\
\hline 2 & $\begin{array}{l}\text { Ongoing since } \\
2010\end{array}$ & $\begin{array}{l}\text { As above, for comparison purposes. } \\
\text { Also to monitor over time NIMC's } \\
\text { interaction with the general public } \\
\text { about the proposed new service }\end{array}$ & $\begin{array}{l}\text { Policy statements and reports from NIMC's website. The } \\
\text { official website address is https://www.nimc.gov.ng. } \\
\text { Reports, policy statements, press releases, etc. can be } \\
\text { found under the Media and Resources tabs. }\end{array}$ \\
\hline 3 & $\begin{array}{l}\text { Autumn } 2013 \\
\text { Spring } 2014 \\
\text { Autumn } 2014\end{array}$ & $\begin{array}{l}\text { To obtain details of Nigerian citizens' } \\
\text { awareness of and experiences with } \\
\text { the identity verification service }\end{array}$ & $\begin{array}{l}\text { Interviews (20) with Nigerian citizens about their } \\
\text { experiences with the identity verification service. }\end{array}$ \\
\hline 4 & $\begin{array}{l}\text { Autumn } 2011 \\
\text { Spring } 2012 \\
\text { Winter } 2013 \\
\text { Summer } 2014\end{array}$ & $\begin{array}{l}\text { To seek expert knowledge about the } \\
\text { nature and scope of different identity } \\
\text { card implementations }\end{array}$ & $\begin{array}{l}\text { Meetings (4) with academic and practitioner experts in } \\
\text { the research area. }\end{array}$ \\
\hline 5 & $\begin{array}{l}\text { Ongoing since } \\
2010\end{array}$ & $\begin{array}{l}\text { To monitor public perceptions about } \\
\text { the Nigerian identity verification } \\
\text { service over time }\end{array}$ & $\begin{array}{l}\text { Press reports about the progress of the service (Agande } \\
\text { 2013; Atili 2012; Eboh 2012; Ekott 2014; Emejor 2014; } \\
\text { Nigerian Tribune 2011; Nnanna 2011; Nwobu 2011; } \\
\text { Planet Biometrics 2011). } \\
\text { Newspapers/blogs: } \\
\text { Nigerian Tribune <http://tribune.com.ng> } \\
\text { The Guardian <http://ngrguardiannews,com> } \\
\text { The Punch <http://www.punchng.com> } \\
\text { Vanguard <http://www.vanguardngr.com> }\end{array}$ \\
\hline 6 & $\begin{array}{l}\text { Ongoing since } \\
2010\end{array}$ & $\begin{array}{l}\text { To assess the possibilities for } \\
\text { achieving the proposed development } \\
\text { goals as an outcome of the identity } \\
\text { verification service in Nigeria }\end{array}$ & $\begin{array}{l}\text { Reports by donor agencies, intergovernmental organi- } \\
\text { zations and Nigerian institutions about Nigeria's } \\
\text { development initiatives (Agbobli and Garba 2007; } \\
\text { Akpobasah 2004; Anyanwu 2005; CBN 2005, 2011; } \\
\text { Demirguc-Kunt and Klapper 2012; Dow 1998; Ebong } \\
\text { 2005; EFInA 2010; Isern et al. 2009; NBS 2010, 2011; } \\
\text { NNPC 2004; Okonjo-Iweala and Osafo-Kwaako 2007; } \\
\text { Sanusi 2010; UNDP 2009a; UNICEF 2007, 2012). } \\
\text { Academic research about financial sector and electoral } \\
\text { reform in Nigeria (Aburime and Alio 2009; Adesina and } \\
\text { Ayo 2010; Akindele 2005; Ayo et al. 2010; Ayo and } \\
\text { Ukpere 2010; Bada 2000, 2002; Briggs and Brooks 2011; } \\
\text { Ehikhamenor 2003; Kotoye 2007; McGrath and Maiye } \\
\text { 2010, 2011; Ojeka and Ikpefan 2011; Ojukwu-Ogba } \\
\text { 2009; Umoh 2006). }\end{array}$ \\
\hline 7 & $\begin{array}{l}\text { Sourced } \\
\text { during } 2010 \\
\text { and } 2011\end{array}$ & $\begin{array}{l}\text { To develop an understanding of the } \\
\text { historical and cultural context for the } \\
\text { proposed intervention }\end{array}$ & $\begin{array}{l}\text { Secondary sources on the sociopolitical and economic } \\
\text { history of Nigeria since it gained independence from } \\
\text { Britain in 1960 (Achebe 1984; Cunliffe-Jones 2010; Maja- } \\
\text { Pearce 2010). }\end{array}$ \\
\hline 8 & Summer 2014 & $\begin{array}{l}\text { To confirm initial propositions about } \\
\text { the developmental potential of identity } \\
\text { verification services }\end{array}$ & $\begin{array}{l}\text { Secondary data about the introduction of identity cards in } \\
\text { the UAE (Al-Khouri 2007; Al-Khouri 2011; Emirates } \\
\text { Identity Authority 2014). }\end{array}$ \\
\hline 9 & Summer 2014 & $\begin{array}{l}\text { To confirm initial propositions about } \\
\text { the developmental potential of identity } \\
\text { verification services }\end{array}$ & $\begin{array}{l}\text { Secondary data about the introduction of identity cards in } \\
\text { Bangladesh (Islam and Gronlund 2010; National Identity } \\
\text { Registration Wing 2014; World Bank 2011). }\end{array}$ \\
\hline
\end{tabular}




\section{Case Study Descriptions}

\section{The Nigerian Identity Verification Service}

Efforts to introduce a national identity card in Nigeria have been ongoing for more than 40 years. In the political instability that existed in the country until 1999, none of the initial efforts produced any useful output (Nwobu 2011). In 2003, a mass registration exercise took place, producing identity cards for about 37 million of the (at that time) more than 70 million eligible citizens and legal residents. The declared development goals of this later project were crime control and government administrative efficiency (NIMC 2009). However, the project failed to achieve these outcomes owing to a lack of necessary infrastructure to support the operational running of the system, the inability to continuously update the registrant database, and a variety of governance concerns (McGrath and Maiye 2011).

The current proposal for implementing identity verification in Nigeria involves issuing a multipurpose smart card to all Nigerian citizens and legal residents aged 16 years and over. The cards will be mandated for use in financial transactions, such as owning and operating bank accounts, and in a range of government services, including the registration of voters, issue of passports and driving licenses, and payment processing of taxes, pensions, and national health insurance. The development goals of the current project, published by the National Identity Management Commission (NIMC) of Nigeria, are financial inclusion, control of crime and illegal immigration, and improved government administrative efficiency (NIMC 2009).

The current project has been managed by NIMC since 2007 and was originally due for implementation in October 2010. However, a dispute with the previous supplier meant that the 2010 completion date was rescheduled to 2013. In 2012, one of NIMC's private partners was unable to obtain finance from the banks (Atili 2012), causing further delays until a new partner, MasterCard, was found. In October 2013, the President ordered citizen registration to be completed by December 2014 (Agande 2013). Yet by March 2014, only 3 million (out of 100 million) citizens were registered (Emejor 2014), and the identity documents were paper-based not smart cards, so the deadline was revised again. Furthermore, there was little evidence of a public awareness campaign, with most participants interviewed up to that time claiming no knowledge of the latest registration exercise (even though they lived and worked in major urban areas such as Lagos and Port Harcourt). Following the launch of the smart card on August 28, 2014, registration commenced as a pilot project for 13 million citizens. Nationwide use of the electronic cards is currently planned for the 2019 elections (Ekott 2014).
Fingerprint biometric verification is being used to identify and disqualify applicants who try to register more than once to acquire multiple identities. Each applicant is allocated a unique national identification number (NIN). Online data capture and real-time update of the central database maintained by NIMC limit opportunities for data corruption and manual intervention. Discretionary procedures for verifying identity in financial transactions should no longer be needed. ${ }^{4}$ An updated IT infrastructure will enable integration of the databases of several government agencies-including the police, the Electoral Commission, the Immigration Service, the National Population Service, and the Federal Road Safety Commission - with the central database. Potentially, then, law enforcement authorities will be able to track each cardholder's participation in a wide range of activities, from applying for a passport or driving license to paying for goods and services; third party organizations, such as banks, will be able to verify identity through the use of card reading devices linked in real-time mode to the central database; and, since the card will be free and mandated for use in many government and business transactions, no applicant should be excluded on the basis that they lack appropriate means of identification. In short, the proposed system promises a wide range of development benefits, while raising the type of civil liberties and security threats outlined earlier.

The turbulent history and minimal outputs produced by the various efforts to implement identity cards in Nigeria have meant that NIMC and its predecessor, the Department of National Civic Registration (DNCR), have been subject to considerable criticism over the years. In 2007, several government officials involved in the 2003 project were indicted on fraud charges (Nnanna 2011). While judgement on the case was delayed on a number of occasions in the Nigerian courts, the French supplier to the project was convicted in a Paris court of paying bribes to the indicted government officials (Eboh 2012).

Two key aspects of the current project are the provision of a payment option on the smart card, allowing it to double as a bank card, and the goal to use the card as a voter identity card during elections. Thus public sentiment about the institutions involved extends not just to government agencies but also to financial sector organizations. In both cases, a key consideration is the prevalence of patrimonialism, that is, a system of governance in which the ruler offers job-related favors to subordinates in return for loyalty and support (Weber 1947)

\footnotetext{
${ }^{4}$ At present, applicants for bank accounts without formal means of identification may be asked to provide at least two references (bank officers or account holders) who can guarantee their identities, or undergo a subjective assessment of their origin (based on accent and local knowledge) which may be subject to opportunistic requests for settlement by the assessor.
} 
and the subordinates have considerable leeway in how they execute their duties, which can mean treating the office as an income-generating role (Brinkerhoff and Goldsmith 2002). Nigerian institutions tend to demonstrate a subtype of patrimonialism, called neo-patrimonialism, in which a patrimonial style of governance coexists with democratic institutions (ibid.).

In the case of the commercial banks, inadequate regulation and a weak judicial system have been key enablers of the patrimonial culture. Consumers have suffered significant losses on several occasions, seriously damaging the credibility of the banks. For example, following liberalization of the industry in 1986, incompetent and often illegal practices flourished in the poorly regulated expanding market (Bada 2000; Ebong 2005). Even after a consolidation and recapitalization exercise in 2004, regulation remained inadequate with the result that the government replaced the leaders at eight banks (Sanusi 2010). More recently, in 2009, following the global financial downturn, oil prices fell, the value of Nigeria's assets decreased, and investors lost heavily (ibid.). All major banks that survived recapitalization have adopted e-payment systems (Ayo et al. 2010). However, the cash in circulation has continued to increase. Only 30 percent of Nigerian adults own bank accounts, the majority of whom are obliged to do so because their salaries and benefits are handled by the e-payment system mandated for disbursements by the government (Demirguc-Kunt and Klapper 2012). Such is the concern about the volume of cash in circulation that the Central Bank of Nigeria (CBN) introduced a "cashless policy" in 2012 to limit individual cash withdrawals from banks (Omose 2012).

In the case of the electoral authorities, the 2007 elections in the country were declared anything but "free and fair" (BBC 2007), so that, in the aftermath, the electoral commission (INEC) was inundated with petitions alleging widespread corruption and other malpractice (McGrath and Maiye 2010). While the 2011 results were deemed much more credible (McGrath and Maiye 2011), support for the government and INEC waned considerably in the following years in light of the political instability in parts of the country (Loschky 2015). In summary, Nigerian citizens have had a poor experience to date with institutions involved in the identity verification project.

\section{The Bangladesh National Biometric Database}

During 2007-2008 the Bangladeshi government built a national biometric database following earlier failed attempts to create a credible voter list for elections and issue voter identity cards. The database covers the entire voting age population, 80 million people. Biometric data stored for each individual includes a digital signature, photograph, and fingerprints. The project was jointly funded by the Bangladeshi government and international donor agencies, including the UNDP (United Nations Development Program). It entailed an extensive public awareness campaign and required collaborative working among the electoral commission, the armed forces, civil societies, religious and community leaders, and the voters themselves.

While the initial goal was to create a reliable voter list, the Bangladeshi government subsequently realized that it "would as a byproduct add the capability of issuing a national ID card to each voter and help to implement e-government initiatives efficiently at a later time" (Islam and Gronlund 2010, p. 190). Thus the developmental potential of the data collected will be realized in stages. Although Bangladeshi law makes it an offence to provide false information, distort the data, or make fraudulent use of the card, legislation does not exist to protect the privacy of the personal information stored in the database.

The broader context for this project is one in which political instability, widespread corruption, and weak leadership had militated against the conduct of free and fair elections since the country gained independence in 1971. Following violent confrontation between the two major political groups, the 2007 election was postponed for nearly two years, while an unelected, military-backed, interim government took power. A key goal of this caretaker government was to create a reliable voter register in time for the rescheduled election in December 2008. This goal was achieved, a credible election took place as planned, and donor evaluation reports declared the project a success (for example, UNDP 2009b).

\section{The UAE National Identity Program}

The UAE national identity program began in 2003 with the goal of registering an anticipated population of 5 million people, about 80 percent of whom were migrant workers. The social marketing approach used to encourage registration had limited success, with the result that, five years later, less than 20 percent of people had enrolled, while the population continued to grow. Thus, in 2010, when the population exceeded 8 million, an alternative approach was adopted linking registration with the issue of residency permits which have a maximum validity of three years. This approach involved publicizing the program in labor camps and at workplaces and installing mobile registration devices in these locations to facilitate enrollment. These methods proved much more successful. The smart identity card incorporates a photograph, digital signature, and fingerprint biometrics. Currently it is being enhanced to deliver further e-government services. 


\begin{tabular}{|c|c|c|c|}
\hline & Nigerian Case & Bangladeshi Case & UAE Case \\
\hline Compulsory? & Yes. & Yes. & Yes. \\
\hline Biometric smart card? & Yes. & Yes. & Yes. \\
\hline Registrant population & Approximately 100 million. & 80 million. & Approximately 8 million. \\
\hline $\begin{array}{l}\text { Political context during } \\
\text { implementation }\end{array}$ & $\begin{array}{l}\text { Weak democracy, } \\
\text { patrimonial institutional } \\
\text { culture. }\end{array}$ & $\begin{array}{l}\text { Strong interim military } \\
\text { government which replaced } \\
\text { an unstable democracy. }\end{array}$ & $\begin{array}{l}\text { Strong authoritarian } \\
\text { federation of emirates. }\end{array}$ \\
\hline $\begin{array}{l}\text { Project implementation } \\
\text { history }\end{array}$ & $\begin{array}{l}\text { Several prior failed attempts } \\
\text { to introduce identity cards. } \\
\text { Multiple delays to the current } \\
\text { project. }\end{array}$ & $\begin{array}{l}\text { Several prior failed attempts } \\
\text { to create a reliable voter list. } \\
\text { National id card was seen as } \\
\text { a by-product of the success- } \\
\text { ful implementation in } 2008 \text {. }\end{array}$ & $\begin{array}{l}\text { Prior attempt to introduce } \\
\text { identity cards in } 2003 \\
\text { recruited less than } 20 \% \text { of } \\
\text { the eligible population. } \\
\text { Successful implementation in } \\
2010 \text {. }\end{array}$ \\
\hline $\begin{array}{l}\text { Limited initial service } \\
\text { delivery? }\end{array}$ & $\begin{array}{l}\text { No, multiple initial services } \\
\text { including payment option, } \\
\text { voter id, and mandatory use } \\
\text { to access a wide range of } \\
\text { government services. }\end{array}$ & $\begin{array}{l}\text { Yes, initially a voter ID card } \\
\text { whose potential to deliver } \\
\text { further services was } \\
\text { exploited after the database } \\
\text { was created. }\end{array}$ & $\begin{array}{l}\text { Yes, initially linked to the } \\
\text { issue of residency permits, } \\
\text { but further services added } \\
\text { since the database was } \\
\text { created. }\end{array}$ \\
\hline $\begin{array}{l}\text { Time-bound registration } \\
\text { period? }\end{array}$ & $\begin{array}{l}\text { No, registration strategy is } \\
\text { not tied to time-bound event. }\end{array}$ & $\begin{array}{l}\text { Yes, bounded by the require- } \\
\text { ment to register for the } 2008 \\
\text { election (11-month period). }\end{array}$ & $\begin{array}{l}\text { Yes, bounded by the } \\
\text { maximum validity of a } \\
\text { residency permit ( } 3 \text { years). }\end{array}$ \\
\hline $\begin{array}{l}\text { Public awareness } \\
\text { campaign? }\end{array}$ & $\begin{array}{l}\text { Minimal before August } 2014 \text {. } \\
\text { Current project still limited to } \\
\text { approximately } 13 \% \text { of the } \\
\text { eligible population. }\end{array}$ & $\begin{array}{l}\text { Extensive, involving civil } \\
\text { societies, religious and } \\
\text { community leaders, and } \\
\text { voters. }\end{array}$ & $\begin{array}{l}\text { Extensive, publicized in labor } \\
\text { camps and at workplaces. }\end{array}$ \\
\hline
\end{tabular}

The broader context for the UAE project is one of political stability in a nondemocratic federation of seven emirates, each ruled by an hereditary emir. Together, the seven emirs form the Supreme Council, which is the highest legislative and executive body in the land. As such, elections are a recent innovation in the UAE. The first elections were held in 2006, when about 2 percent of eligible Emirati citizens were allowed to vote - but only to elect half of the Federal National Council, which has an advisory role to the emirs. At the latest election in 2011, the government gave 12 percent of eligible citizens the right to vote. Nevertheless, despite widespread political unrest across the Middle East during 2011 in the socalled Arab Spring, the UAE remained stable, although it did introduce Internet restrictions in 2012 to hinder the use of social media to organize political protests (BBC 2014).

Historically, the UAE has been very dependent on oil revenues which were used to develop public services such as health, education, and the national infrastructure (ibid.). More recently, the country has developed its construction and tourist industries, particularly in Dubai, attracting increasing numbers of migrant workers. Despite its conservatism in some respects, the discourse of modernization is prevalent in the country, not least in the business and technology sectors. Thus both the infrastructure and the political will exist in the country to adopt technology innovations and, specifically, to develop further services linked to the identity card. A comparison of the three cases described in this section is provided in Table 2 .

\section{Case Analysis}

Earlier, the argument was presented that simultaneous trust and distrust can coexist as separate dimensions of the same relationship (Lewicki et al. 1998). Specifically, where distrust is highly likely in one dimension (for example, personal privacy relating to compulsory use of biometric-based identity cards), trust in other dimensions may be high or low, giving rise to ambivalence or suspicion respectively in the relationship overall. This analysis suggests that the repeatedly poor outcomes in the Nigerian case are the result of suspicion, that is, negative sentiment across multiple dimensions of the citizen-state relationship, whereas the more successful outcomes in the Bangladesh and UAE cases result from 
ambivalence in the relationship. In this paper, trust and distrust are defined, respectively, as confident positive and confident negative expectations regarding another's conduct (Lewicki et al. 1998). This section presents a comparative analysis which outlines the manifestations of trust and distrust in each case and explains what gives rise to such conditions in the first place. In this way, the question of why some countries are more successful than others with introducing identity verification services is addressed.

\section{Manifestations of Sentiment about the Nigerian Identity Verification Project}

There is a stark contrast between the development benefits highlighted by the directorate of NIMC, its business and technical partners, and strategy documents (NIMC 2007, 2009), and perceptions in the media and among citizen participants in this study about the likely outcomes from the Nigerian identity verification project. Primary and secondary data from this study reveal that the sentiment of the former group has remained largely positive since its inception in 2007, emphasizing the development benefits for citizens while presenting implementation problems and delays as a legacy of prior implementations by the DNCR, NIMC's predecessor. Nevertheless, almost all interviewees in this group mentioned the threat of corruption, given the endemic nature of patrimonialism at all levels in Nigerian public administration and the fact that many staff transferred from the DNCR to NIMC when the latter was created in 2007 . What was less apparent in this discourse was evidence of concerted action to deal with this threat.

By contrast, citizen participants expressed largely negative sentiment, ranging from disappointment about the performance of their government to cynicism about its motives for introducing identity cards. Referring to the 2003 implementation, one participant claimed that cards were not issued to registrants in a state other than their state of origin, lest funding and other resources were redistributed on the basis of card issuances, while another claimed that numbers were inflated at some registration centers by issuing cards to underage applicants. In the independent press, the 2003 project is frequently referred to as a "scam" (Eboh 2012; Nnanna 2011). When the budget for the latest implementation was announced in 2011, criticism reemerged. Immediate reactions in the press described the scheme as "another white elephant" (Nigerian Tribune 2011). Crucially, though, the group of citizen participants interviewed two years later, in 2013-2014, either had no knowledge that a new registration exercise was underway, or expressed concern, even conviction, that the project would be a further waste of billions of naira (several hundred million U.S. dollars).
The high profile launch of the electronic card on August 28, 2014 , in which dozens of VIPs were filmed during registration, contrasts sharply with interviewees' experiences to obtain their paper-based cards. One participant with a personal contact at NIMC expressed concerns about poorly planned implementation processes. Others highlighted limited public awareness about the registration exercise, several hour waits to register, and inadequate facilities (buildings, electricity supply, etc.) for registration purposes. Where public awareness had existed among study participants prior to the launch of the e-card, it had occurred either by word of mouth or because a citizen had needed to renew a document which required identity verification, for example, a driving license. While the August 2014 launch heightened the profile of the project, it also introduced a new dimension because the e-card is branded with the MasterCard logo. Protests across the country expressed outrage that the biometrics of Nigerian citizens would be shared with a U.S.-based corporation which would also benefit financially from having access to over 100 million customers (Ekott 2014). Thus, concerns about threats to civil liberties assumed a major role, along with fears that, if implemented, the benefits of the service would not accrue to Nigerians themselves.

In short, not only has there been a lack of public confidence in NIMC's ability to deliver the system, but also a feeling that political will to prosecute endemic fraud on the project was lacking (Nigerian Tribune 2011). In effect, public sentiment has been one of suspicion of institutions and their leaders resulting from poor project outcomes enabled by weak governance systems. As their annual reports have made clear, NIMC's management team were aware of "the very deep cynicism" (NIMC 2010, p. 14) in the country and the need to build public confidence in the system in light of past experience. However, their response to criticism has been less than transparent and accountable. Between 2007 and 2010, a high degree of secrecy was maintained about the actual status of the project until the October 2010 implementation date was passed, when it became necessary to acknowledge that minimal development work had taken place in the previous three years. As late as spring 2014, there was little evidence of a public awareness campaign, even among well-educated participants from major urban areas. In short, policymakers' claims about the development potential of the service seem to be underpinned by the common assumption in e-government research in DCs that if they do a competent job on the technical task, trust will follow (Avgerou et al. 2009).

\section{The Roots of Suspicion}

The coexistence of low trust and high distrust between Nigerian citizens and their institutions is a very undesirable 
situation in which individuals express little or no reason for confidence in the implementation of the identity verification service and ample reason for skepticism and, indeed, cynicism about the declared development goals. Their experience with earlier and current efforts to introduce identity cards has been plagued by corrupt and incompetent practice, yet minimal action has been taken to identify those responsible and hold them accountable. Almost as soon as identity cards were issued from the 2003 project, they fell out of use, once realization surfaced of the static and inaccurate nature of the data collected. There is little evidence so far that the latest implementation will instill the confidence that is lacking. Far from creating a nationwide awareness campaign to publicize the new service, and educate citizens in the potentialities of the card and the situations in which it can or must be used, the implementation team provided minimal information about the progress of the project between 2007 and 2014. Thus, implementation experience to date is a significant contributor to the non-conducive context for this initiative since it does not provide reasons for positive expectations about the conduct of those responsible for delivering the service.

However, the absence of positive expectations coexists with negative expectations that undesirable events will occur. Development outcomes claimed for the use of the identity verification service include financial inclusion, resulting from increased access to consumer credit, and more representative election results, resulting from a reliable voter register (NIMC 2007, 2009). However, Nigerian citizens' experiences with their elections and their banks (Bada 2002; Ehikhamenor 2003; McGrath and Maiye 2010) at the very best leave room for wariness, and in most cases, skepticism and cynicism prevail (Loschky 2015). European Union observers at the 2007 elections alleged that they were the worst they had witnessed in any country, and even though the 2011 elections restored some confidence among the electorate, support for the government had nearly halved by 2014 (ibid.). Furthermore, INEC continued to engage in identity capture and data storage independently of NIMC, to the extent that it issued its own biometric voter cards for the 2015 elections. Yet, this approach also has been problematic. With only weeks to go, the country's national security adviser urged INEC to postpone the election for up to three months, since 30 million cards had still to be distributed (BBC 2015b). In the end, it was postponed for six weeks and resulted in defeat for the incumbent government - the first time in Nigeria's history that an opposition candidate was successful in a presidential election (BBC 2015a).

Suspicion of the banks is also crucial, given the inclusion of a payment option on the card. For years, weak governance has allowed borrowers to renege on their loans, knowing that the banks were unlikely to pursue them in court given the slow and expensive nature of Nigeria's legal process (Sanusi 2010). Some borrowers have done this repeatedly with different banks (Ebong 2005) since the country lacks the infrastructure to establish credit ratings for borrowers and a standardized address system for authenticating demographic data. While the owners and managers of the failed banks and their bad debtors escaped prosecution, small savers lost heavily, eroding their trust in the formal system (EFInA 2010). Indeed, 65 percent of the economically active population is served by the informal financial sector or financially excluded, rising to 98 percent in rural areas (CBN 2005, 2011). The poor, especially, tend to keep their savings as "resources in kind" (CBN 2005) and continue to engage in cash-based transactions. Those who choose to save and borrow in the informal financial sector find the available products more suitable to their needs in terms of simplicity, interest rate levels, and little or no need for collateral they would be unable to provide (Komolafe 2011; Umoh 2006). Furthermore, high participation in the formal sector is better explained by compulsion than confidence in some cases, such as government workers who own bank accounts because this is the means of payment for their salaries.

Lamido Sanusi was appointed Governor of the CBN, in June 2009 , for a five-year term in the middle of the world financial crisis. He was an internationally acclaimed banker who came to office with a radical anti-corruption agenda and spoke publicly about citizens' lack of trust in Nigerian banks on several occasions (for example, Sanusi 2010). However, he was suspended from office by the President in February 2014 after exposing a $\$ 20$ billion fraud committed in the stateowned Nigerian National Petroleum Company (NNPC) involving ministers in the President's regime. One of the citizen participants in this study pointed to Sanusi's suspension as further reason for skepticism that Nigerian banks were becoming more trustworthy, and, as in the case of the elections, this view of institutions in the country was widely shared (Ross 2014).

Summarizing so far, secure reliable means of identification are a necessary and legitimate requirement for individuals to claim their right of citizenship and access associated public and business services. There can be few who would argue that financial inclusion, reliable voter registration, and other benefits claimed for the introduction of identity verification services are desirable outcomes for Nigerian citizens. However, conditions in Nigeria are not conducive to the introduction of such a service. Instrumental freedoms (Sen 1999) are lacking, in particular, the social arrangements called transparency guarantees, which allow individuals to interact with others on some basic presumption of trust. So is Nigeria a special case? How have identity verification services been successfully implemented elsewhere, for example, in Bangla- 
desh and the United Arab Emirates, and what constitutes a conducive context for such a service?

\section{The Bangladesh National Biometric Database}

Islam and Gronlund (2010) analyze the success factors associated with building a national biometric database in Bangladesh in 2008 following earlier failed attempts to do so. The database covers the entire voting age population, 80 million people, and was built with the goal of creating a credible voter list for elections. The Bangladeshi government subsequently realized that the database could be used to produce a national ID card for each voter and provide the basis for implementing e-government services in the future. Islam and Gronlund ask if this project is a transferable success. Clearly, there are similarities with the Nigerian case: a history of political instability, entrenched corruption and weak governance, and past failure to implement the project. However, there are also some crucial differences. The project was implemented under a military-backed interim government in a "politically controlled environment" in which there were "positive exercises of power and politics" (ibid., p. 200). As Islam and Gronlund suggest, strong political regimes might accept such an approach, but it is less transferable to a weak democracy. Nigeria is the latter case (Kelsall 2011), and a key contributor to its weakness is the size of and rivalry between its two main ethnic groups, split almost 50:50 within the population.

Other important differences between the Bangladeshi and Nigerian cases are also apparent. First, creating a credible voter register followed by a free and fair election was a precondition in Bangladesh for the restoration of democracy, and a massive awareness campaign ensured that citizens were informed of the need to register. By contrast, return to a democratic dispensation occurred in Nigeria in 1999 and has remained so since, notwithstanding the terrorist activities of Boko Haram in the north of the country. Second, the Bangladeshi project was more limited than the Nigerian one, focusing only on a voter list with an ID card as a by-product, increasing confidence that it could be achieved in a reasonable timescale. In Nigeria, the initiative aims to harmonize the databases of several government agencies as well as including a payment option on the smart card. Third, NIMC publicizes financial inclusion as a goal of the Nigerian initiative. Aside from the high distrust in Nigerian banks, the benefits to Nigeria's "unbanked" of the payment option on the card will be limited, for although the card will be free to all citizens, the services planned for delivery will not be. A crucial issue for Nigeria's financially excluded is obtaining small loans without collateral (Komolafe 2011). In Bangladesh, alternative arrangements exist to provide such loans to the poor. The Grameen Bank is a high profile example, which together with its founder, Muhammad Yunus, won a Nobel Peace Prize in 2006.

In short, it seems clear that the political will existed in Bangladesh in 2008 to make the national biometric database a success, aided by support from donor agencies, including the UNDP. However, Islam and Gronlund's account is tempered not just by comment about the politically controlled environment, but also about the need for citizen trust in e-government services. In effect, this initiative may be seen as one that ultimately built trust (that a successful implementation would be achieved and the democracy restored), but such trust coexisted with distrust (not least, concerns about the security of the data and how the government might use it), which necessitated political control by a military-backed regime in order to collect it. As in the case of the pension recipient mentioned earlier in this paper, this trust/distrust combination is one in which the parties have separate as well as shared objectives, hence it can be beneficial to both if their interdependence is suitably bounded (Lewicki et al. 1998). Whether and how such bounding is maintained in Bangladesh in the longer term is an open question. Indeed, further research could usefully explore how the relationship between Bangladeshi citizens and institutions unfolds over time.

\section{The UAE National Identity Program}

Al-Khouri's (2011) study of the successful implementation of the UAE national ID program presents an alternative contextmechanism-outcome configuration. The political regime in the UAE is a federation of seven emirates, each ruled by an hereditary emir. In this case, the right to vote is limited to a small percentage of the eligible population who can elect advisors to the emirs only. Thus, the impetus for the introduction of the UAE national ID card was not linked to the creation of an eligible voter list. Rather the issue was national security, given the political instability among some of the UAE's neighbors and its high ratio of expatriate workers of approximately 5:1 when compared with Emirati citizens. This initiative got off to a slow start in 2003 until changes were made to the registration process. A key revision was to link registration for the card with the issue and renewal of residency permits, which run for a maximum of three years, creating a time-bound plan for data collection. In this way, support was enlisted from the Ministry of the Interior (including the immigration suthorities and the police force), the Ministry of Health (since medical fitness certificates are needed to complete the residency procedures) and the Ministry of Labor. In short, the development goal in this case was neither about franchise nor financial inclusion, but concerned the more fundamental freedom of establishing one's right to reside in a country. 
As in the Bangladeshi case, the UAE ID card project worked to a time-bound plan for registration with coordinated action across several ministries; it was implemented by a stable nondemocratic political regime, with support from the immigration authorities and the police; and it separated the delivery of the basic facilities to support national security from the delivery of e-government services. The UAE initiative had a strong theme of development as modernization, with a key focus on the use of information technology. Indeed, the identity commission of the country is now expanding the range of services it offers to citizens, including the use of apps on smart phones. Such an approach makes the most of the well-developed infrastructure in the country, although it contrasts significantly with the more traditional style of government, which is making much slower progress toward participation. Again, though, a workable combination of trust and distrust was achieved in this case, despite the significant differences between the political, social, and economic contexts of the UAE and Bangladesh, a combination that is not yet being achieved in Nigeria.

\section{Consolidating Empirical Findings on Identity Verification}

The consolidating concept among these empirical observations is the manifestation of trust and distrust in the citizenstate relationship. In the UAE and Bangladeshi cases, this manifestation was ambivalence, in which the shared goal of restoring democracy or ensuring national security generated sufficient levels of trust in a successful implementation outcome to enable the introduction of identity cards. Furthermore, citizens were aware that the authorities intended to enforce registration and, therefore, that resistance would be penalized. In the Nigerian case, there is limited evidence of belief in a successful implementation and a wide-ranging set of development goals which make achieving a workable level of trust among citizens an uphill struggle. Combined with high levels of distrust about the institutions involved, what manifests itself is not ambivalence but skepticism (that this initiative will again be undermined by corruption) without reassurance (that measures are in place to deal with such threats)-in short, suspicion.

What are the mechanisms that give rise to the necessary level of trust to convert suspicion about identity verification into ambivalence, and what practical implications does this have for the Nigerian case? First, the evidence suggests the importance of a circumscribed development goal, which is widely publicized, broadly shared, and achievable in the short term. In the Nigerian case, the wide range of development goals from financial inclusion to immigration control tend to confuse rather than provide a means for consensus, height- ening speculation about the government's real agenda. Distrust of the government's motives, particularly around issues of security and privacy, is a reality for the introduction of identity verification in any country. Experience from the Bangladeshi and UAE cases suggests that such negative expectations can coexist with goals that generate positive sentiment, such as political freedoms and national security. However, to generate such sentiment, citizens in all parts of the country must be made aware of what is planned, how it will be achieved, and what it means for them, which will involve recruiting appropriate civil society support, for example, from religious and community leaders.

Second, the logistics of registering 100 million citizens, many of whom live in remote rural and even hostile terrain, coupled with Nigeria's infrastructure problems, make registration a huge task. Success seems more likely if this task is attempted separately from the provision of financial and e-government services. Until recently, NIMC was attempting to register all citizens by the end of 2014, but completion of registration has now been delayed until 2018 in time for the 2019 elections (Ekott 2014). Potentially, this approach could represent a first stage of the project, as in Bangladesh, with services to follow at a later date, although it seems unlikely that MasterCard, NIMC's business partner for the payment option on the card, will want to wait that long. Furthermore, cooperation between NIMC and INEC would need to move on from its current position of independent operation. Whether registration is coordinated with the production of a voter list or not, lessons from the UAE and Bangladesh suggest that timebounding it with an important, or necessary, event for citizens is a successful strategy.

Third, and crucially, strong governance is a key determinant of success. Although Nigeria is seen as a weak democracy, if NIMC, as the institution responsible for identity verification, establishes its credibility, then trust in this initiative seems likely to increase. Indeed, Avgerou (2013) shows how the Brazilian people came to trust their electoral authorities and as a result successfully implemented an e-voting system, despite their distrust of politicians and public administration more widely. However, NIMC is unlikely to achieve such trust without the kind of active public engagement evident in the Bangladeshi and UAE cases.

\section{Conclusion}

This research was premised on the view that ambivalence and suspicion are crucial concepts in explaining why some governments are more successful than others with introducing identity verification services. In this context, ambivalence is defined as coexistent trust and distrust toward a single target, 
while suspicion implies only negative sentiments (such as skepticism, cynicism, distrust) across all dimensions of the relationship (Lewicki et al. 1998). Based on this premise, the goal of this research was to derive the social (or generative) mechanisms that give rise to these different manifestations of trust and distrust, that is, to identify the structures, processes, and events that explain empirical observations in different identity verification cases. As such, the research had theoretical and practical intent.

The findings from this research are that ambivalence is an appropriate concept for explaining the successful introduction of identity verification services. Realistically, such services will always generate some distrust among citizens due to the amount of personal data they are required to disclose to powerful executive and legislative bodies. Nevertheless, identity verification is a necessary and legitimate requirement for individuals to benefit from both the services offered in a country and the security of residency rights within itopportunities and capabilities which contribute to their development. Therefore, it is appropriate to consider how such verification can be achieved, particularly in countries where secure, reliable means of identification are not commonplace. This research traced the outcomes from a, to-date, unsuccessful attempt to introduce such a service in Nigeria and then analyzed two further cases to identify the structures and processes that led to the necessary trust-building for successful outcomes after initially unpromising beginnings. The consolidating concept among these cases was the trust/ distrust combination that prevailed between the institutions responsible for the initiatives and the citizens intended to benefit from them. These tendencies manifested themselves as suspicion in the Nigerian case and as ambivalence in the more successful cases. The social mechanisms that accounted for these outcomes were concerned with the structures and processes through which a circumscribed, time-bound development goal for the service was established; appropriate institutional and civil society support was enrolled; and confidence was built in the responsible authorities through a citizen engagement strategy.

The theoretical implications of this research take the form of rudimentary propositions which may be refined in further empirical studies. First, ambivalence toward identity verification services is not just productive in ensuring a successful implementation, but also necessary to ensure ongoing use. Such ambivalence is produced in the tension between the security and privacy concerns of the registrants and the positive sentiment generated by government strategies to raise public awareness, build confidence in institutions, and address broadly shared development goals. Such strategies are necessary during both implementation and use. Second, the absence of ambivalence is likely to give rise to problems with identity verification in implementation or use, irrespective of whether it results from positive or negative sentiment across the related dimensions of the citizen-state relationship. In either case, one may argue that the citizen's response is blind - either blind trust or blind suspicion (Lewicki et al. 1998). Hence necessary monitoring, confidence building, and consensus seeking strategies are likely to be largely absent, and even unsought, leaving the service open to manipulation and abuse. Third, a growing body of ICTD research is informed by Sen's (1999) capability framework which postulates a link between services and observable outcomes through the concept of capabilities, or notions of freedom that allow people to live lives of their choosing (De' 2007; Hatakka and Lagsten 2012; Kleine et al. 2012; Zheng and Walsham 2008). However, just as trust coexists with distrust toward a single target and the two may be combined in a productive relationship, so freedom coexists with unfreedom, and again, the two can work together to achieve a particular development outcome. Such coexistence is evident in the notion of developmental patrimonialism (Kelsall 2011), which is used to describe regimes where rapid and poverty-reducing growth has taken place under strong leadership which, nevertheless, tolerated and controlled processes of economic rentseeking, while remaining oriented toward the long term. In short, some of the generative mechanisms identified in this paper as causal explanations of empirical observations contain coercive elements, yet outcomes such as the restoration of democracy in a country are widely perceived as bringing development benefits for citizens. Societal challenges such as those discussed in this paper raise ethical and moral dilemmas, opening up an area of information systems research that has received limited attention to date.

Further empirical studies on identity verification might also take the following research directions. First, the mechanisms identified may be unpacked further. In any societal level study, one risks missing or smoothing away important contextual details in an aggregation process. A focus on key groups within the society may reveal the presence of other mechanisms which at a societal level cancel each other out. Second, this research focused on two key objectives of the Nigerian identity card project: financial inclusion and reliable voter registration. However, there are a number of other objectives, such as tackling crime and illegal immigration, each of which merit a study in their own right. There is scope for comparative studies of identity card projects and their related development goals. Some initial comparisons with projects in the UAE and Bangladesh have been made that merit more detailed investigation. Brazil is a frequently cited example in Nigerian policy documents, suggesting a place where further work might be progressed. Finally, identity verification services are justified by governments on the basis of achieving two broad goals: supporting national security 
and improving access to services. In the longer term, then, findings from this stream of work may contribute to wider research domains such as e-government.

\section{Acknowledgments}

The author would like to thank the following people for their help with this paper: Ann Majchrzak for her advice and support as senior editor; Chioma Ezenwa for insightful conversations on Nigeria and introductions to several of the participants in this study; Ariyo Maiye for some initial data collection at NIMC; and Edgar Whitley for introducing me to the finer points of identity card systems. Any errors or omissions rest with the author.

\section{References}

Aburime, U. T., and Alio, F. 2009. "Islamic Banking: Theories, Practices and Insights for Nigeria," International Review of Business Research Papers (5:1), pp. 321-339.

Achebe, C. 1984. The Trouble with Nigeria, London: Heinemann. Adesina, A. A., and Ayo, C. K. 2010. "An Empirical Investigation of the Level of Users' Acceptance of E-Banking in Nigeria," Journal of Internet Banking and Commerce (15:1), pp. 1-13.

Agande, B. 2013. "Jonathan Orders NIMC to Register All Nigerians by Dec, 2014," Vanguard, (www.vanguardngr.com/ 2013/10/jonathan-orders-nimc-register-nigerians-dec-2014; retrieved February 27, 2014).

Agbobli, F. M., and Garba, A. 2007. "Support to the Development of Sustainable Microfinance Sector in Nigeria: Mid-Term Evaluation Report," UNDP/UNCDF (United Nations Development Program/United Nations Capital Development Fund) (http://www.ng.undp.org/publications/poverty/microfinance.pdf; retrieved September 15, 2011).

Akindele, S. T. 2005. "A Critical Analysis of Corruption and its Problems in Nigeria," Anthropologist (7:1), pp. 7-18.

Akpobasah, M. 2004. "Development Strategy for Nigeria," paper presented at the Overseas Development/Nigerian Economic Summit Group Meeting, London, June 16-17.

Al-Khouri, A. M. 2007. "UAE National ID Programme Case Study," International Journal of Social Sciences (1:2), pp. 62-69.

Al-Khouri, A. M. 2011. "Targeting Results: Lessons Learned from UAE National ID Program," in Proceedings of the 2011 International Conference on Industrial Engineering and Operations Management, Kuala Lumpur, Malaysia, pp. 104-111.

Allonby, N. 2009. "Identity Cards: A Global Perspective," Nexus (16:6), pp. 11-16.

Anyanwu, C. 2005. "Microfinance Institutions in Nigeria: Policy, Practice and Potentials," paper presented at the G24 Workshop, Pretoria, South Africa, November 29-30 (http://www.g24.org/ Workshops/anyanwu.pdf; retrieved September 15, 2011).

Atili, A. 2012. "Banks Impede National ID Card Project," (http://www.thenationonlineng.net/2011/index.php/feed/busine ss $/ 40975$-\% E2\% 80\%98banks-impede-national-id-cardproject $\% \mathrm{E} 2 \% 80 \% 99 . t x t$; retrieved March 30, 2012).
Avgerou, C. 2008. "Information Systems in Developing Countries: A Critical Research Review," Journal of Information Technology (23:3), pp. 133-146.

Avgerou, C. 2013. "Explaining Trust in IT-Mediated Elections: A Case Study of E-Voting in Brazil," Journal of the Association for Information Systems (14:8), pp. 420-451.

Avgerou, C., Ganzaroli, A., Poulymenakou, A., and Reinhard, N. 2009. "Interpreting the Trustworthiness of Government Mediated by Information and Communication Technology: Lessons from Electronic Voting in Brazil," Information Technology for Development (15:2), pp. 133-148.

Ayo, C. K., Adewoye, J. O., and Oni, A. A. 2010. "The State of E-Banking Implementation in Nigeria: A Post-Consolidation Review," Journal of Emerging Trends in Economics and Management Sciences (1:1), pp. 37-45.

Ayo, C. K., and Ukpere, W. I. 2010. "Design of a Secure Unified E-Payment System in Nigeria: A Case Study," African Journal of Business Management (4:9), pp. 1753-1760.

Bada, A. 2000. "Institutional Intervention in the Adoption of Computer-Based Information Systems (CBIS): The Case of the Nigerian Banking Industry," in Information Technology in Context: Studies from the Perspective of Developing Countries, C. Avgerou and G. Walsham (eds.), Aldershot, UK: Ashgate Publishing, pp. 168-181.

Bada, A. 2002. "Local Adaptations to Global Trends: A Study of an IT-Based Organizational Change Programme in a Nigerian Bank," The Information Society (18:2), pp. 77-86.

BBC. 2007. "Elections in Nigeria," British Broadcasting Corporation (http://news.bbc.co.uk/1/hi/world/africa/281978.stm; retrieved August 28, 2007).

BBC. 2014. "United Arab Emirates Profile," British Broadcasting Corporation (http://www.bbc.co.uk/news/world-middle-east14703998?print=true; retrieved January 15, 2015).

BBC. 2015a. "Nigeria Election: Muhammadu Buhari Wins Presidency," British Broadcasting Corporation (http://www.bbc. co.uk/news/world-africa-32139858; retrieved June 12, 2015).

BBC. 2015b. "Nigeria Elections: Security Chief Urges Vote Delay," British Broadcasting Corporation (http://www.bbc. co.uk/news/world-africa-30938612?print=true; retrieved January 23, 2015

Briggs, A., and Brooks, L. 2011. "Electronic Payment Systems Development in a Developing Country: The Role of Institutional Arrangements," Electronic Journal of Information Systems in Developing Countries (49:3), pp. 1-16.

Brinkerhoff, D., and Goldsmith, A. 2002. "Clientelism, Patrimonialism and Democratic Governance: An Overview and Framework for Assessment and Programming," IQC\# AEP-I-0000-00005-00, Task Order No. 4801-003-01, Abt Associates, Inc., Cambridge, MA.

Bryman, A. 2001. Social Research Methods, New York: Oxford University Press.

CBN. 2005. "Microfinance Policy, Regulatory and Supervisory Framework for Nigeria," Central Bank of Nigeria, (http://www.cenbank.org/OUT/PUBLICATIONS/GUIDELIN ES/DFD/2006/MICROFINANCE\%20POLICY.pdf; retrieved October 15, 2011). 
CBN, 2011. "Microfinance Policy Framework for Nigeria: Revised-April 29, 2011," Central Bank of Nigeria (http://www.cenbank.org/Out/2011/pressrelease/gvd/Revised\% 20Microfinance $\% 20$ Policy\%20July\%2012\%202011.pdf; retrieved October 15, 2011).

Cunliffe-Jones, P. 2010. My Nigeria: Five Decades of Independence, New York: Palgrave Macmillan.

De', R. 2007. "The Impact of Indian E-Government Initiatives: Issues of Poverty and Vulnerability Reduction," UNCRD: Regional Development Dialogue (27:2), pp. 88-100.

Demirguc-Kunt, A., and Klapper, L. 2012. "Measuring Financial Inclusion: The Global Financial Index Database," The World Bank, Washington, DC.

Dow, U. 1998. "Birth Registration: The 'First' Right," The Progress of Nations 1998, United Nations International Children's Educational Fund (UNICEF) (http://www.unicef.org/ pon98/06-13.pdf; retrieved September 15, 2011).

Eboh, M. 2012. "N34bn ID Card Scam: French Court Fines Coy for Bribing Nigerian Officials," Vanguard (www.vanguardngr. com/2012/09/n34bn-id-card-scam-french-court-fines-coy-forbribing-Nigerian-officials; retrieved August 20, 2014).

Ebong, B. B. 2005. "The Banking Industry and the Nigerian Economy Post-Consolidation," Union Bank of Nigeria PLC. (http://www.unionbankng.com/ebong.pdf; retrieved September 15, 2011).

EFInA. 2010. "Access to Financial Services in Nigeria 2010 Survey," Enhancing Financial Innovation and Access (EFInA) (http://www.efina.org.ng/media-centre/news/access-to-financialservices-in-nigeria-survey-2010/; retrieved September 15, 2011).

Ehikhamenor, F. 2003. "Information Technology in Nigerian Banks: The Limits of Expectations," Information Technology for Development (10:1), pp. 13-24.

Ekott, I. 2014. "SCANDALOUS: Outrage in Nigeria as Government Brands National ID Card with MasterCard's Logo," (www.premiumtimesng.com/featured-news/167479-scandalousoutrage-in-nigeria-as-government-brands-national-id-card-withmastercards-logo.html\#sthash.g97BG99m.dpbs; retrieved August $30,2014)$.

Emejor, C. 2014. "NIMC Begins National ID Cards Issuance Next Week," Daily Independent, May 22 (http://dailyindependentnig. com/2014/05/nimc-begins-national-id-cards-issuance-next-week; retrieved August 6, 2014).

Emirates Identity Authority. 2014. "Official Website," (http://www.id.gov.ae/en/home.aspx; retrieved August 10, 2014).

Hatakka, M., and Lagsten, J. 2012. "The Capability Approach as a Tool for Development Evaluation-Analyzing Students' Use of Internet Resources, "Information Technology for Development (18:1), pp. 23-41.

Heeks, R. 2002. "Information Systems and Developing Countries: Failure, Success, and Local Improvisations," The Information Society (18:2), pp. 101-112.

Isern, J., Agbakoba, A., Flaming, M., Mantilla, J., Pellegrini, G., and Tarazi, M. 2009. "Access to Finance in Nigeria: Microfinance, Branchless Banking and SME Finance," Consultative Group to Assist the Poor, World Bank (http://www.microfinancegateway. org/library/access-finance-nigeria-microfinance-branchlessbanking-and-sme-finance; retrieved October 15, 2011).
Islam, M. S., and Gronlund, A. 2010. "The Bangladesh National Biometric Database: A Transferable Success?," in Proceedings of EGOVIS (International Conference on Electronic Government and the Information Systems Perspective) 2010, K. N. Andersen, E. Francesconi, A. Gronlund, and T. van Engers (eds.), Bilbao, Spain, pp. 189-203.

Kelsall, T. 2011. "Developmental Patrimonialism? Rethinking Business and Politics in Africa," Policy Brief, June (www.knstitutions-africa.org; retrieved March 23, 2012).

Kleine, D., Light, A., and Montero, M.-J. 2012. "Signifiers of the Life We Value? Considering Human Development, Technologies and Fair Trade from the Perspective of the Capabilities Approach," Information Technology for Development (18:1), pp. 42-60.

Komolafe, B. 2011. "Seven Fundamental Flaws with Microfinance Banking in Nigeria," (http://www.vanguardngr.com/ 2011/09/seven-fundamental-flaws-with-microfinance-banking-innigeria/; retrieved October 24, 2011).

Kotoye, O. 2007. "ePayment for all Nigerians," Card Technology (January/February), pp. 18-22.

Lewicki, R., McAllister, D., and Bies, R. 1998. "Trust and Distrust: New Relationships and Realities," Academy of Management Review (23:3), pp. 438-458.

Loschky, J. 2015. "Ahead of Poll, Few Nigerians Trust in Elections," Gallup (http://www.gallup.com/poll/180914/aheadpoll-few-nigerians-trust-elections.aspx; retrieved January 14, 2015).

Luhmann, N. 1979. Trust and Power, Chichester, UK: Wiley.

Maja-Pearce, A. 2010. "Africa at 50: Wind of Change-Episode Two," BBC Radio 4, 19 October.

McGrath, K. 2013. "The Potential of Generative Mechanisms for IS Research," in Proceedings of the $34^{\text {th }}$ International Conference on Information Systems, Milan, Italy.

McGrath, K., and Maiye, A. 2010. "The Role of Institutions in ICT Innovation: Learning from Interventions in a Nigerian E-Government Initiative," Information Technology for Development (16:4), pp. 260-278.

McGrath, K., and Maiye, A. 2011. "The Contribution of ICTs to Socio-Economic Development: Experience from Nigeria," in Proceedings of the $7^{\text {th }}$ Critical Management Studies Conference, Naples, Italy.

National Identity Registration Wing. 2014. "Bangladesh Electoral Commission Official Website," Election Commission Bangladesh (http://www.nidw.gov.bd/; retrieved August 10, 2014).

NBS. 2010. "The Review of the Nigerian Economy 2010," National Bureau of Statistics of Nigeria (http://www. nigerianstat.gov.ng/ext/latest_release/2010_Review_of_the Nigerian_Economy.pdf; retrieved February $2 \overline{3}, 2012$ ).

NBS. 2011. "Annual Socio-Economic Report on Nigeria," National Bureau of Statistics of Nigeria (http://www.nigerianstat.gov.ng/uploads/latestRelease/2ff063b 27de8aa15b35fla6fb04bf472c658d939.pdf; retrieved February 23, 2012).

Nigerian Tribune. 2011. "New National ID Card Scheme: Another Multibilion Naira White Elephant Project?" (http://www.tribune.com.ng/sat/index.php/features/5605-new- 
national-id-card-scheme-another-multibillion-naira-whiteelephant-project.html; retrieved October 24, 2011).

NIMC. 2007. "National Policy and Institutional Framework for an Identity Management System for Nigeria" (http://www.nimc.gov.ng; retrieved September 15, 2010).

NIMC. 2009. "Overview of the National Identity Management System Infrastructure Upgrade Project," National Identity Management Commission, Abuja, Nigeria.

NIMC. 2010. “Annual Report 2010,” National Identity Management Commission, Abuja, Nigeria.

Nnanna, O. 2011. "Justice Oniyangi and the ID Scam Case," Vanguard (http://www.vanguardngr.com/2011/10/justiceoniyangi-and-the-id-scam-case/; retrieved October 15, 2011).

NNPC. 2004. "Meeting Everyone's Needs: Nigerian Economic Empowerment and Development Strategy (NEEDS)," Nigerian National Planning Commission (http://siteresources. worldbank.org/INTPRS1/Resources/Nigeria_PRSP(Dec2005). pdf; retrieved October 15, 2011).

Nwobu, I. W. 2011. "Nigeria: Same Old Tale About National ID Card," AllAfrica (http://allafrica.com/stories/201111211444. html; retrieved March 15, 2012).

Ojeka, S. A., and Ikpefan, O. A. 2011. "Electronic Commerce, Automation and Online Banking in Nigeria: Challenges and Benefits," School of Doctoral Studies European Union Journal (3), pp. 39-50.

Ojukwu-Ogba, N. 2009. "Banking Sector Reforms in Nigeria: Legal Implications for the Banker-Customer Relationship," Commonwealth Law Bulletin (35:4), pp. 675-686.

Okonjo-Iweala, N., and Osafo-Kwaako, P. 2007. "Nigeria's Economic Reforms: Progress and Challenges," The Brookings Institution, March 23 (http://www.brookings.edu/research/ papers/2007/03/23globaleconomics-okonjo-iweala; retrieved March 12, 2012).

Omose, K. 2012. "Lamido Sanusi's Trap," Vanguard, September 10 (http://www.vanguardngr.com/2012/09/lamido-sanusis-trap; retrieved August 30, 2014).

Pawson, R. 2000. “Middle-Range Realism,” European Journal of Sociology (41:2), pp. 283-325.

Planet Biometrics. 2011. "Nigerian National ID Doubles as Bank Card," September 26 (http://www.planetbiometrics.com/articledetails/i/838; retrieved September 30, 2011).

Privacy International. 2011. “Official Website," (https://www. privacyinternational.org/; retrieved October 15, 2011).

Ramakumar, R. 2010. "The Unique ID Project in India: A Skeptical Note," in Ethics and Policy of Biometrics, A. Kumar and D. Zhang (eds.), Berlin: Springer-Verlag, pp. 154-168.

Ramanathan, U. 2014. "Biometrics Use for Social Protection Programmes in India Violating Human Rights of the Poor," United Nations Research Institute for Social Development (UNRISD) May 2 (http://www.unrisd.org/sp-hr-ramanathan; retrieved November 24, 2014).

Ross, W. 2014. "Is Nigeria Serious About Tackling Corruption?," BBC News (http://www.bbc.co.uk/news/world-africa26535530?print=true; retrieved August 31, 2014).

Sanusi, S. L. 2010. "The Nigerian Banking Industry: What Went Wrong and the Way Forward," Governor's Speech, Central
Bank of Nigeria, February 26 (http://www.cenbank.org/out/ speeches $/ 2010 /$ the $\% 20$ nigerian $\% 20$ banking $\% 20$ industry $\% 20 \mathrm{w}$ hat $\% 20$ went $\% 20$ wrong $\% 20$ and $\% 20$ the $\% 20$ way\%20forward final 260210.pdf; retrieved September 15, 2011).

Sayer, A. 2000. Realism and Social Science, London: Sage Publications.

Sen, A. 1999. Development as Freedom, Oxford, UK: Oxford University Press.

Umoh, G. 2006. "Empirical Investigation of Access to MicroCredit in an Emerging Economy: Evidence from Nigeria," Journal of African Business (7:1/2), pp. 89-117.

UNDP. 2009a. "Human Development Report Nigeria 2008-09," United Nations Development Program (http://www.ng.undp.org/ documents/NHDR2009/NHDR_MAIN-REPORT_20082009.pdf; retrieved February 23,2012).

UNDP. 2009b. "PERP Evaluation Report," Dhaka: United Nations Development Program, December.

UNICEF. 2007. "Information Sheet: Birth Registration," United Nations International Children's Educational Fund (http://www.unicef.org/wcaro/WCARO_Nigeria_Factsheets_ BirthRegistration.pdf; retrieved October 12,2011$)$.

UNICEF. 2012. "Nigeria Statistics," United Nations International Children's Educational Fund (http://www.unicef.org/ infobycountry/nigeria_statistics.html; retrieved March 5, 2012).

Weber, M. 1947. The Theory of Social and Economic Organization, New York: Free Press.

Whitley, E., Gal, U., and Kjærgaard, A. 2014. "Who Do You Think You Are? A Review of the Complex Interplay Between Information Systems, Identification and Identity," European Journal of Information Systems (23:1), pp. 17-35.

Whitley, E., and Hosein, G. 2010a. Global Challenges for Identity Policies, Basingstoke, UK: Palgrave Macmillan.

Whitley, E., and Hosein, G. 2010b. "Global Identity Policies and Technology: Do We Understand the Question?," Global Policy (1:2), pp. 209-215.

World Bank. 2011. "Project Appraisal Document on a Proposed Credit in the Amount of SDR 123 million (US\$195 million equivalent) to the People's Republic of Bangladesh for the Identification System for Enhancing Access to Services (IDEA) Project" (http://www-wds.worldbank.org/external/default/ WDSContentServer/WDSP/IB/2011/04/21/000371432_201104 21103040/Rendered/PDF/606070PAD0P1215280IDA1R2011 1012811.pdf; retrieved August 1, 2014).

World Bank. 2014. "Making Everyone Count: Identification for Development" (http://live.worldbank.org/making-everyonecount; retrieved October 13, 2014).

Yadav, V. 2013. "Unique Identification Project for 1.2 Billion People in India: Can it Fill Institutional Voids and Enable 'Inclusive' Innovation?" (http://southasiainstitute.harvard.edu/ website/wp-content/uploads/2013/07/VANITA-Working-PaperSAI_UID-Project-Institutional-Voids-Inclusive-Innovation.pdf; retrieved November 24, 2014).

Zheng, Y., and Walsham, G. 2008. "Inequality of What? Social Exclusion in the E-Society as Capability Deprivation," Information Technology and People (21:3), pp. 222-243. 


\section{About the Author}

Kathy McGrath is a senior lecturer in Information Systems at Brunel University, London. Her research focuses on the relationship between information and communication technologies (ICTs) and socio-organizational change. She has studied the use of ICTs in personal, professional, and civic society contexts. Her most recent research focuses on the role of ICTs in humanitarian emergencies and the implications for current concepts of organizing, mobilization, and engagement. She has previously published in leading journals such as MIS Quarterly, Information Systems Journal, European Journal of Information Systems, Information and Organization and Information Technology and People. 